\title{
EKSPLORASI KEKAYAAN SENI DAYAK NGAJU DI DESA TUMBANG MANGGU KABUPATEN KATINGAN
}

\author{
Pepe Rusmitha Agel, Nur Khasanah, Muslimah, Hernes Demar Wulan, Eli Karliani, \& \\ Triyani \\ Universitas Palangka Raya \\ rusmithaagel123@gmail.com
}

\begin{abstract}
Abstrak
Suku Dayak Ngaju memiliki kekayaan dalam hal kesenian. Suatu ciri yang dijumpai dalam kebudayaan Dayak Ngaju adalah kemampuan menyerap kebudayaan dari luar. Bahkan proses perpaduan dan pembauran kebudayaan tersebut dilakukan sedemikian rupa sehingga tidak dapat disangkal bahwa ada juga kelompok - kelompok dari orang Dayak Ngaju yang meninggalkan kebudayaannya sendiri. Penelitian ini bertujuan untuk mengetahui macam - macam kesenian yang terdapat di Desa Tumbang Manggu, bagaimana kesenian tersebut dibuat dan apa saja manfaat serta kegunaannya, upaya apa saja yang dilakukan oleh masyarakat Desa Tumbang Manggu untuk tetap menjaga kesenian tersebut agar tidak hilang seiring zaman. Pendekatan yang digunakan dalam penelian ini adalah kualitatif deskriftif dan metode yang digunakan adalah wawancara, dokumentasi dan observasi. Hasil dari penelitian ini menyatakan bahwa Suku Dayak Ngaju yang ada di Desa Tumbang Manggu Kecamatan Sanaman Mantikei Kabupaten Katingan Kalimantan Tengah, memiliki kesenian yang beragam. Mulai dari kesenian tari, musik, menganyam, memahat dan melukis. Seiring berkembangnya zaman dan teknologi yang semakin canggih nilai-nilai kesenian daerah mulai pudar dan perlahan hilang. Untuk mencegah hal itu terjadi masyarakat Desa Tumbang Manggu membentuk sebuah sanggar dan memperkenalkan kesenian daerah kepada pelajar yang ada di daerah tersebut, agar kesenian tidak dilupakan oleh generasi penerus dan ada hingga masa yang akan datang. Dari sanggar yg didirikan ini lah para pelajar mempelajari kesenian tari, musik, meganyam, memahat dan melukis serta memperkenalkan kepada masyarakat luas dengan cara mengikuti lomba-lomba yang ada.
\end{abstract}

Kata kunci :Kesenian; Adat Istiadat Dayak; Suku Dayak Ngaju; Desa Tumbang Manggu

\begin{abstract}
The Ngaju Dayak tribe has a wealth of art. A characteristic found in the Ngaju Dayak culture is the ability to absorb culture from outside. In fact, the process of cultural integration and assimilation is carried out in such a way that it cannot be denied that there are also groups of Ngaju Dayak people who have left their own culture.This study aims to find out the various arts found in Tumbang Manggu Village, how the art is made and what are the benefits and uses, what efforts are made by the people of Tumbang Manggu Village to keep the art from being lost over time. The approach used in this research is descriptive qualitative and the methods used are interviews, documentation and observation. The results of this study indicate that the Ngaju Dayak tribe in Tumbang Manggu Village, Sanaman Mantikei District, Katingan Regency, Central Kalimantan, has a variety of arts. Starting from the arts of dance, music, weaving, sculpting and painting. Along with the development of the times and increasingly sophisticated technology, the values of regional art began to fade and slowly disappear. To prevent this from happening, the people of Tumbang Manggu Village formed a studio and introduced local arts to students in the area, so that the arts were not forgotten by the next generation and existed for the future. From the studio that was established, the students learned the arts of dance, music, weaving, sculpting and painting and introduced them to the wider community by participating in existing competitions.
\end{abstract}

Keywords: Art; Dayak Customs; Ngaju Dayak Tribe; Fallen Manggu Village

\section{PENDAHULUAN}

Kesenian merupakan salah satu bagian dari kebudayaan yang muncul dan berkembang sebagai produk dan aktifitas kehidupan manusia termasuk didalamnya cipta, rasa dan karsa. Sebagai salah satu 
bagian dari kebudayaan, kesenian akan bergerak dan berkembang apabila kebudayaan mengalami perubahan. Kesenian adalah suatu kompleks dari ideide, gagasan, nilai-nilai, norma- norma, dan peraturan dimana kompleks aktivitas dan tindakan berpola dari manusia dalam masyarakat dan biasanya berwujud bendabenda hasil manusia (Koentjaraningrat, 2007: 53) (Nurgiansah, 2020b).

Kesenian rakyat merupakan kesenian tradisional yang keberadaannya bersifat turun-temurun.Sifat turun-temurun inilah yang mengakibatkan kesenian tradisional mengalami perubahan dan perkembangan sesuai dengan perubahan-perubahan yang terjadi dalam masyarakat. Seni-budaya merupakan suatu keahlian mengekspresikan ide-ide dan pemikiran estetika, termasuk mewujudkan kemampuan serta imajinasi pandangan akan benda, suasana, atau karya yang mampu menimbulkan rasa indah sehingga menciptakan peradaban yang lebih maju (Harry Sulastianto 2001:64).

Kalimantan Tengah mempunyai problem etnisitas yang sangat berbeda di banding Kalimantan Barat. Mayoritas ethnis yang mendiami Kalimantan Tengah adalah etnis Dayak, yang terbesar suku Dayak Ngaju, Ot Danum, Maanyan, Dusun, dsb. Sedangkan agama yang mereka anut sangat variatif. Dayak yang beragama Islam di Kalimantan Tengah, tetap mempertahankan ethnisnya Dayak, demikian juga bagi Dayak yang masuk agama Kristen (Soemadio, Budaya Masyarakat Dayak, 2010).

Suku Dayak Ngaju memiliki kekayaan dalam hal kesenian. Diantaranya yang paling menonjol adalah seni tari dan seni vokal. Tarian daerah yang sering ditampilkan didepan publik adalah tari mandau, tari manasai dan tari burung merak. Seni vokal yaitu berupa lagu-lagu daerah baik dinyanyikan pakai musik maupun tanpa musik. Suatu ciri yang dijumpai dalam kebudayaan Dayak Ngaju adalah kemampuan menyerap kebudayaan dari luar. Bahkan proses perpaduan dan pembauran kebudayaan tersebut dilakukan sedemikian rupa sehingga tidak dapat disangkal bahwa ada juga kelompokkelompok dari orang Dayak Ngaju yang meninggalkan kebudayaannya sendiri. Khususnya kebiasaannya dalam pola hidup yang sudah berubah menjadi bidang pertanian menetap dan ada juga yang berpola hidup sebagai industri barang dan jasa(Kumpiadi \& Drs., 2009).

Kesenian masyarakat Desa Tumbang Manggu sangat beragam, fokus masalah penelitian ini yaitu; (1) Apa saja macammacam kesenian yang terdapat di Desa Tumbang Manggu, (2) Apa manfaat kesenian untuk masyarakat Desa Tumbang Manggu, (3) Bagaimana Upaya masyarakat di Desa Tumbang Manggu untuk tetap menjaga agar kesenian tersebut tidak hilang seiring zaman. Dengan mengetahui kesenian masyarakat di sana dapat memberikan gambaran bagi masyarakat luas bagaimana kesenian suku dayak ngaju yang ada di desa Tumbang Manggu. Serta mendorong masyarakat dasa tumbang manggu agar mengembangkan kesenian guna melestarikan kesenian yang ada.

Seni menurut Soedarso (1990 : 1) adalah segala macam keindahan yang diciptakan oleh manusia. Seni telah menyatu dalam kehidupan sehari - hari setiap manusia, baik bagi dirinya sendiri maupun dalam bermasyarakat. Seni berhubungan dengan ide atau gagasan dan perasaan manusia yang melakukan kegiatan berkesenian. Sumardjo (2000 : 4) mengatakan bahwa seni merupakan ungkapan perasaan yang dituangkan dalam media yang dapatdidengarmaupun dilihat. Dengan kata lain, seni adalah isi jiwa seniman (pelaku seni) yang terdiri dari perasaan dan intuisinya, pikiran dan gagasannya. 
Selanjutnya menurut Banoe (2003 : 219), kesenian adalah karya indah yang merupakan hasil budi daya manusia dalam memenuhi kebutuhan jiwanya.suku dayak ngaju merupakan salah satu dari sekian banyak suku dayak yang ada di provinsi Kalimantan Tengah, yang hingga kini masih terus ada keberadaanya. Kelompok suku Dayak, terbagi lagi dalam sub-sub suku yang kurang lebih jumlahnya 405 sub (menurut J. U, Lontaan, 1975). Masingmasing sub suku Dayak di pulau Kalimantan mempunyai adat istiadat dan budaya yang mirip, merujuk kepada sosiologi kemasyarakatannya dan perbedaan adat istiadat, budaya, maupun bahasa yang khas. Masa lalu masyarakat yang kini disebut suku Dayak, mendiami daerah pesisir pantai dan sungai-sungai di tiap-tiap pemukiman mereka (Soemadio, Budaya Masyarakat Dayak, 2010).

\section{METODE PENELITIAN}

Penelitian ini dilakukan di Desa Tumbang Manggu, Kecamatan Sanaman mantikei, Kabupaten Katingan. Pendekatan yang digunakan dalam penelitian ini adalah pendekatan kualitatif yang mana pendekatan penelitian yang berfokus pada pemahaman terhadap fenomena sosial yang terjadi di masyarakat.

Pengumpulan data menggunakan metode wawancara, observasi dan dokumentasi. Wawancara adalah percakapan dengan maksud tertentu (Nurgiansah, 2020a).

Percakapan itu dilakukan oleh dua pihak, yaitu pewawancara (interviewer) yang mengajukan pertanyaan dan terwawancara (interview) yang memberikan jawaban atas pertanyaan itu (Lexy J. Meleong, 2010: 186).

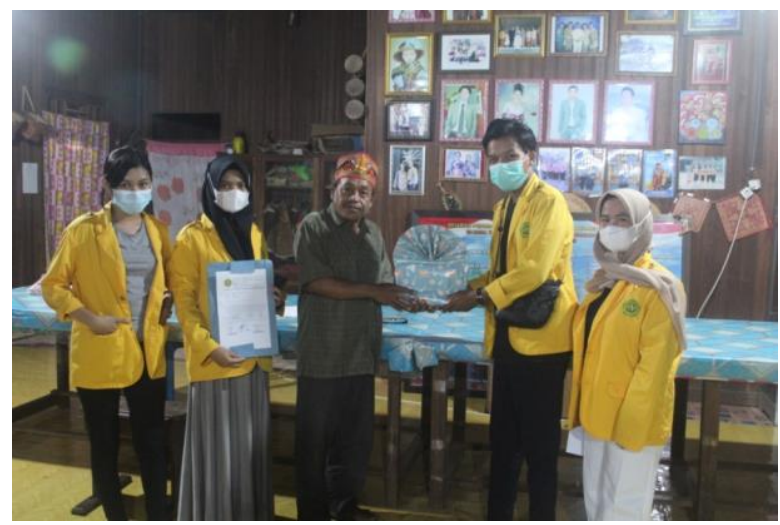

Gambar 1

Observasi merupakan aktivitas penelitian dalam rangka mengumpulkan data yang berkaitan dengan masalah penelitian melalui proses pengamatan langsung di lapangan. Peneliti berada ditempat itu, untuk mendapatkan buktibukti yang valid dalam laporan yang akan diajukan. Observasi adalah metode pengumpulan data dimana peneliti mencatat informasi sebagaimana yang mereka saksikan selama penelitian (W. Gulo, 2002: 116). Penggunaan dokumen sudah lama digunakan dalam penelitian sebagai sumber data karena dalam banyak hal dokumen sebagai sumber data dimanfaatkan untuk menguji, menafsirkan, bahkan untuk meramalkan (Lexy J. Moleong, 2010: 217).

\section{HASIL PENELITIAN DAN PEMBAHASAN Hasil Penelitian}

Kesenian dalam perkembangannya sudah menjadi bagian dari sendi kehidupan yang tak terpisahkan dalam masyarakat baik di dunia umumnya ataupun di negeri kita pada khususnya. Ditanah air kita Indonesia, kesenian telah menempati tempat tersendiri sebagai salah satu bidang yang diakui dalam masyarakat, baik itu kesenian tradisional maupun kesenian modern (Nurgiansah, 2021). Daerah Kalimantan khususnya Kalimantan Tengah dikenal sangat kaya dengan ragam jenis kesenian tradisional. Kesenian tradisional itu merupakan kesenian daerah yang hidup 
tersebar hampir di Kalimantan. Kehadirannya sebagai sarana hiburan, masih diminati dan digemari oleh masyarakat pendukungnya, oleh karena itu tidak heran jika alat-alat kesenian yang dipergunakan dalam seni pertujukannya, sangat beragam dan banyak jenisnya.

\section{Pembahasan}

\section{a) Macam-Macam Kesenian Desa Tumbang Manggu}

Kesenian tradisional dalam tulisan berikut dilihat sebagai identitas cultural masyarakat pendukungnya tidak sekedar sebagai hiburan yang menciptakan kegembiraan, namun ia juga menjadi media yang mampu memfasilitasi doa dan harapan mereka. Kendatipun penyajian kesenian tradisional saat ini mengalami perubahan berbagai gaya dan variasi. Termasuk di Desa Tumbang Manggu ini sudah bayak mengalami variasi dalam bidang kesenian. Kesenian di desa ini beragam diantaranya kesenian dalam bidang musik, tarian, anyaman, pahat dan lukisan.

1. Kesenian Musik

Dari hasil wawancara tokoh adat, kesenian musik di Desa Tumbang Manggu sudah eksis di kalangan masyarakatnya, kesenian musik ini biasa di sebut dengan "karungut " yang mana karungut ini diciptakan sendiri oleh masyarakat setempat dan dijadikan sebagai hiburan dikala waktu senggang seperti acara kumpul keluarga, nikahan dan lain sebagainya. Karungut ini biasanya dinyanyikan dengan iringan kecapi/rabab. Adapun makna dibalik lagu ini adalah sebagai pengingat "penyang hidup". Karungut adalah sebuah kesenian tradisional dari Kalimantan Tengah.

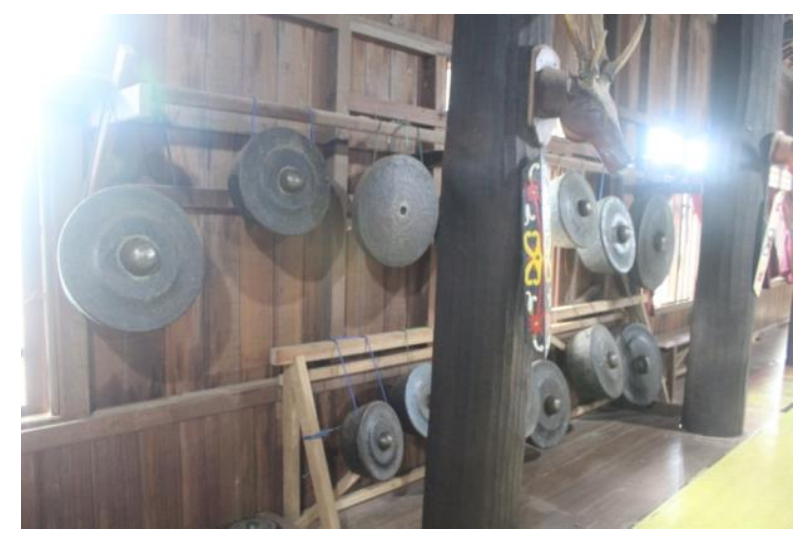

Gambar 2

Seni ini berupa sastra lisan atau juga bisa disebut pantun yang dilagukan. Karungut merupakan karya yang dijunjung masyarakat Dayak sebagai sastra besar klasik dan merupakan semacam pantun atau gurindam. Dalam berbagai acara karungut sering di lantunkan, misalnya pada acara penyambutan tamu yang di hormati salah satu ekspresi kegembiraan dan rasa bahagia di ungkapkan dalam bentuk karungut (Romein Armando, 2021) Alat musik yang digunakan seperti kecapi, rabab, organ dan alat lainnya sebagai pengiring. Untuk alat music tradisonal sendiri alat sudah terdesain bentuk dan fungsinya masing-masing, sehingga bisa menghasilkan bunyi yang diinginkan. Contohnya gong, gong memiliki berbagai macam bentuk dan ukuran yang dimiliki oleh masing-masin alat music tersebut. Dan juga pada alat pemukul gong itu berbeda, ada yang menggunakan rotan, kayu dan lain-lain sehingga menghasilkan suara yang berbeda pula.

\section{Kesenian Tari}

Kesenian tari di Desa Tumbang Manggu telah mengalami banyak variasi yang di ciptakan oleh para masyarakat dan para pelajar di sana. Adapun kesenian tari yang yang selalu ada yaitu tarian manasai, tarian dadas dan masih banyak lagi tarian lainnya. Banyaknya masyarakat pendatang dari luar Desa Tumbang Manggu telah mengajarkan tarian-tarian baru, yang mana 
dipimpin sendiri oleh Bapak Siyaff Wahid K. dengan cara menggabungkannya menjadi satu sehingga tercipta tarian baru yang dihasilkan, yang dinamakan tari kreasi.

Bentuk dalam sebuah tari adalah wujud atau rupa yang membantu mengkomunikasikan gagasan dari penari untuk menyajikan tarian kepenonton tidak hanya gerak melainkan struktur-struktur yang telah direncanakan dan disusun oleh penari untuk memberikan bentuk keseluruhan dari elemen-elemen yang terdapat dalam tari berupa tema, gerak, iringan, busana, ruang, penari, tata rias, property. Menurut Soedarsono (1986:7) Seni tari merupakan ungkapan perasaan yang dinyatakan dengan gerakan-gerakan tubuh manusia.

Tari Manasai merupakan tari pergaulan Suku Dayak Ngaju sebagai ungkapan rasa suka cita kebersamaan dan kekeluargaan. Manasai dalam Bahasa Dayak Ngaju berasal dari kata manasa atau gerakan kaki atau maasa laseh (mengasah lantai). Biasanya manasai mengelilingi lunuk sangkai atau rangkaian dahan lunuk dan bendera merah putih dan bendera bahalai yang diletakkan ditengah sebagai simbol kebulatan tekad dan semangat persatuan dan kesatuan menjunjung tinggi falsafah Huma Betang yaitu dimana bumi dipijak disitu langit dijunjung.

Tari Manasai juga sering dilakukan pada saat acara hiburan atau penyambutan tamu yang datang ke Kalimantan Tengah. Tua atau muda, bisa menari atau tidak, semuanya harus ikut menari manasai bersama-sama. Karena pada saat menari manasai semuanya berbaur menjadi satu, dan ini membuat mereka menjadi semakin akrab satu sama lain. (Edlin Yanuar Nugraheni, 2018)

\section{Kesenian Menganyam}

Kesenian menganyam ini sudah ada sejak dulu, yang mana telah digunakan sebagai alat pemenuh kebutuhan hidup. Di Desa Tumbang Manggu kesenian mengayam ini masih terjaga dan masih eksis dikalangan masyarakat. Dengan bahan baku (rotan dan bambu) maka dari itu kesenian ini mudah di dapat para masyarakat, jadi tidak perlu membeli bahan baku tersebut karena sudah tersedia di alam.

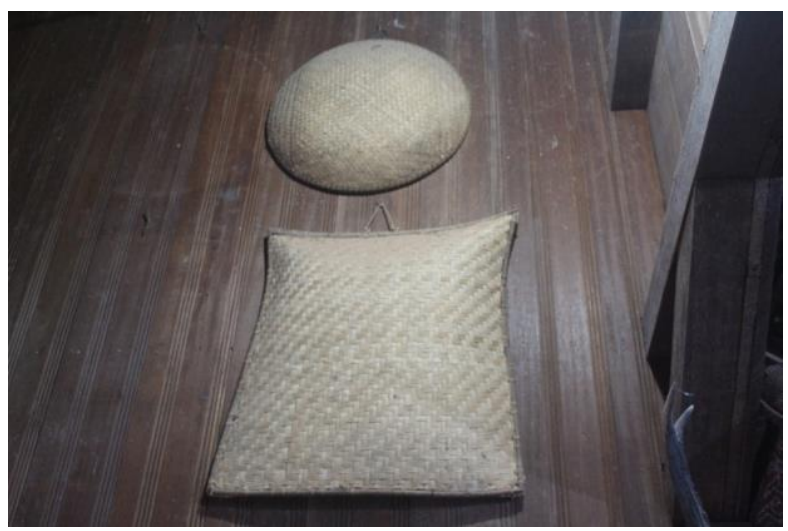

Gambar 3

Contoh dari kesenian menganyam ini adalah etang (semacam tasransel suku dayak), kusak (tas jinjing suku dayak), tapan (untuk membersihkan beras dari remah-remah kulit padi) dan nyiru (tempat menyimpan bahan makanan), Sauk, Buwu, Takalak, Tangilang (alat penangkap ikan).

a) Motif dan makna dari ayaman

1) Batang garing, Batang garing atau Pohon Kehidupan juga melambangkan keseimbangan atau keharmonisan hubungan antara sesama manusia, manusia dengan alam, dan manusia denganTuhan (katabung, 2018).

2) Kariau (siluman/hantu hutan), Memiliki makna yang bertujuan agar dapat membantu dalam mendapatkan hasil buruan atau pancingan.

3) Bunga jeruk, Bunga jeruk memiliki makna sebagai penangkal roh jahat bagi ibu/perempuan yang sedang hamil atau kincir anggin sebagai putaran kehidupan. 
4) Mata ikan, Motif ini melimiki makna dari kejelian dalam menjalani kehidupan.

5) Sengkakau belalang, Sangkakau belalang memiliki makna sebagai fase kehidupan yang terkadang naik dan terkadang turun.

6) Paku-pakuan/pakis, Sebagai sayur yang sering dikomsumsi masyrakat Dayak dan juga sebagai gambaran lika-liku kehidupan.

\section{Kesenian Memahat Dan Melukis}

Kesenian melukis ini biasanya di temukan di talawang dan sapundu. Untuk talawang sendiri dapat di gunakan dua kesenian yaitu bisa di ukir dan bisa di lukis. Sedangkan untuk sapundu (patung) harus dipahat. Bagian yang menarik disini, pada kesenian sapundu. Tidak banyak orang tahu apa itu sapundu, tak terkecuali orang dayak sekitar.

\section{1) Talawang}

Talawang adalah tameng atau perisai suku dayak yang terbuat dari kayu ulin atau kayu besi. Talawang berbentuk persegi panjang yang dibuat runcing pada bagian atas dan bawahnya. Panjang talawang sekitar 1 sampai dengan 2 meter dengan lebarmaksimal $50 \mathrm{~cm}$. Sisi luar talawang dihias dengan ukiran yang mencirikan kebudayaan Dayak, sementara bagian dalamnya diberi pegangan. Keseluruhan bidang depan talawang biasanya diukir berbentuk topeng (hudo). Konon, ukiran pada talawang memiliki daya magis yang mampu membangkitkan semangat hingga menjadikan kuat orang yang menyandangnya. Ukiran talawang pada umumnya bermotifkan burung tingang, yaitu burung yang dianggap suci oleh suku dayak. Selain motif burung tinggang, motif lain yang sering digunakan adalah ukiran kamang. Kamang merupakan perwujudan dari roh leluhur Suku Dayak. Motif kamang digambarkan dengan seseorang yang sedang duduk menggunakan cawat dan wajahnya berwarna merah. Walaupun setiap subSuku Dayak mengenal kebudayaan mandau dan talawang, ternyata penggunaan warna dan motif ukiran pada talawang berbedabeda. Motif ukiran pada talawang ini juga yang kemudian banyak dijumpai sebagai desain interior rumah serta bagian-bagian arsitektural dari kriya seni ukir Dayak.

\section{(a) Nilai Filosofis}

Seperti juga peralatan adat lainya, Talawang juga memiliki nilai-nilai filosofis yang terkadung didalamnya, yang mana menggambarkan kearifan lokal Suku Dayak yang senantiasa dijaga secara turun temurun, adapun nilai-nilai yang terkandung di dalam Talawang dari segi Fungsi Harfiahnya Talawang berfungsi untuk menangkis bahaya, ancaman, atau serangan yang tidak terduga, dalam kehidupan sehari-hari manusia akan selalu dihadapkan pada tekanan hidup dan kebutuhan yang tidak terprediksi (ekonomi, pendidikan dan kesehatan), untuk itu penting bagi setiap orang untuk melakukan antisipasi.

Sebagai Simbol Sosial Talawang juga bermanfaat sebagai simbol sosial, hal tersebut tergambar dari ukiran yang terdapat pada talawang yang menggambarkan flaura dan fauna dan manusia. Dalam kehidupan masyarakat dayak sangatlah penting menjalin hubungan yang harmonis antara alam sekitar maupun dengan sesama umat manusia. Dalam budaya adat dayak, telawang diartikan sebagai identitas yang dibangun dan dijaga harmonisasinya secara mengakar, hal itu dimaksudkan untuk menjamin masa depan generasi selanjutnya (Umberan, 2015).

\section{2) Sapundu}

Sapundu adalah sebagai tempat mengikat hewan korban, seperti kerbau, sapi, atau babi yang digunakan dalam suatu 
acara adat tiwah. Tiwah sendiri, merupakan sebuah upacara ritual agama untuk mengantarkan roh orang yang telah meninggal menuju kehidupan abadi.

Sapundu memiliki 2 motif yaitu:

(a) Motif laki-laki yang bearti jasad yang meninggal atau di tiwahkan adalah Wanita

(b) Motif perempuan yang bearti jasad yang meninggal atau ditiwahkan adalah laki-laki

Untuk memasang dan menanam Sapundu, ada ritual khusus yang harus dilakukan, seperti dengan memotong babi. Karena menjadi pengikat hewan korban pada upacara tiwah, sapundu biasanya ditempatkan di lokasi pelaksanaan tiwah.

Setelah upacara selesai, Sapundu dicabut lalu didirikan di depan sandung keluarga yang ditiwahkan. Sapundu dipasang berdampingan dengan Sandung rumah-rumahan yang menjadi tempat bagi tulang belulang orang yang ditiwahkan. Ini sebagai bentuk pengawalan sapundu kepada roh tersebut. (yandi, 2014).

Sapundu ini tidak sembarang orang yang menggunakannya, ternyata hanya suku Dayak yang mempunyai agama Kaharingan yang mewajibkan adanya Sapundu. Sapundu diciptakan untuk menghormati orang yang lebih dahulu meninggalkan sanak saudara untuk selamanya. Bahan pembuatan Sandung dan Sapundu, harus dari kayu ulin agar tahan lama dan tidak rapuh.

Dengan pikiran yang telah ditanamkan oleh leluhur bahwa kita hidup tidak untuk melebarkan atau mempersempit kehidupaan. Jadi pada suku Dayak Kaharingan ketika meninggal dan telah dipindah tempatkan ke Sandung, lubang kuburan yang ada dimanfaatkan kembali untuk orang yang meninggal kelak begitu seterusnya.
3) Mandau

Mandau merupakan senjata utama dan merupakan senjata turun temurun yang dianggap keramat. Bentuknya panjang dan selalu ada tanda ukiran baik dalam bentuk tatahan atau hanya ukiran biasa. Mandau dibuat dari batu gunung, ditatah, diukir dengan emas/perak/tembaga dan dihiasi dengan bulu burung atau rambut manusia. Mandau mempunyai nama asli yang disebut "Mandau Ambang Birang Pono Ajun Kajau", merupakan barang yang mempunyai nilai religius, karena dirawat dengan baik oleh pemiliknya. Batu-batuan yang dipakai sebagai bahan dasar pembuatan Mandau dimasa yang telah lalu yaitu: Batu Sanaman Mantikei, Batu Mujat atau Batu Tengger, Batu Montalat (Soemadio, Budaya Masyarakat Dayak, 2010, hal. 4) Untuk kesenian alat seperti Mandau sudah menjadi hal yang lumrah adanya disetiap suku Dayak Kalimantan. Ukuran serta bentuknya hanya menyesuaikan ke kreativitasan si pembuat. Mandau menjadi jati diri suku Dayak memang sangat penting dimiliki untuk identitas diri dan tempat kita berada.

\section{4) Dohong}

Senjata ini semacam keris tetapi lebih besar dan tajam sebelah menyebelah. Hulunya terbuat dari tanduk dan sarungnya dari kayu. Senjata ini hanya boleh dipakai oleh kepala-kepala suku, Demang, Basir (Soemadio, Budaya Masyarakat Dayak, 2010, hal. 4).

\section{b) Manfaat Kesenian Untuk Mayarakat Tumbang Manggu}

Kesenian adalah daya kreativitas manusia yang dapat kita nikmati melalui panca indra, beberapa kesenian di Desa Tumbang Manggu selalu dihadirkan pada kegiatan upacara adat, hiburan, kegiatan keagamaan yang memiliki bentuk, fungsi dan pemaknaan yang berbeda pada 
masyarakat dan daerah setempat. Kesenian dapat dikatakan sebagai keindahan karena merupakan komponen-komponen kesenian yang menjadikan keterpaduan sistemik.

Komponen-komponen

pembentuknya yaitu perangkat nilai-nilai dan konsep-konsep yang merupakan pengarah bagi keseluruhan kegiatan berkesenian, para pelaku kesenian (seniman perancang, seniman penyaji, pengayom dan penikmat) tindakantindakan terpola dan terstruktur yang berkaitan dengan seni (kebiasaan berlatih, berkarya, publikasi). Benda-benda yang terkait dengan proses kesenian baik alat yang di gunakan sebagai alat maupun yang dihasilkan sebagai karya seni.

Tujuan orang melakukan kegiatan seni yaitu untuk menghasilkan keindahan. Adanya perangkat instrumental tertentu diperlukan agar keindahan yang dituju dapat dicapai. Sehingga dihasilkannya sebuah tradisi yang akan selalu dapat mempertemukan pihak seniman dan pihak penikmat. Manfaaat kesenian untuk masyarakat Tumbang Manggu dibagi menjadi 3 yaitu :

\section{Kesenian yang bersifat sacral}

Kesenian ini meliputi kesenian tari, dan musik. Biasanya kesenian ini digunakan untuk suatu acara adat. Contohnya adalah Sangiang merupakan budaya suku Dayak Kalimantan Tengah, yang di dalamnya ada unsur pengobatan.

Tujuan dari dilaksanakannya sangiang bukan hanya sebagai sarana pengobatan semata, tetapi seringkali pula sangiang digunakan untuk menjauhkan segala marabahaya suatu kampung dari gangguan roh-roh jahat atau murka leluhur yang disebut mamapas lewu atau tolak bala, ada pula yang mengadakan sangiang di lokasi kerja seperti pertambangan emas, sarang walet dan lokasi-lokasi pekerjaan lainnya, sangiang dilakukan agar lokasi pekerjaan aman dari segala gangguan dan melancarkan segala pendapatan. Contohnya adalah Sangiang merupakan sebuah budaya suku Dayak Kalimantan Tengah, yang di dalamnya ada unsur pengobatan.

Tujuan dari dilaksanakannya sangiang bukan hanya sebagai sarana pengobatan semata, tetapi seringkali pula sangiang digunakan untuk menjauhkan segala marabahaya suatu kampung dari gangguan roh-roh jahat atau murka leluhur yang disebut mamapas lewu atau tolak bala, ada pula yang mengadakan sangiang di lokasi kerja seperti pertambangan emas, sarang walet dan lokasi-lokasi pekerjaan lainnya, sangiang dilakukan agar lokasi pekerjaan aman dari segala gangguan dan melancarkan segala pendapatan

\section{Kesenian yang bersifat hiburan}

Kesenian ini meliputi kesenian tari, musik, anyaman, pahat dan lukisan. Masyarakat bisa secara bebas melakukannya. Contohnya adalah Sastra lisan adalah karya sastra yang berbentuk ujaran. Salah satu sastra lisan di Kalimantan Tengah adalah karungut. Karungut adalah sebuah kesenian tradisional dari Kalimantan Tengah. Seni ini berupa sastra lisan atau juga bisa disebut pantun yang dilagukan. Karungut merupakan karya yang dijunjung masyarakat Dayak sebagai sastra besar klasik dan merupakan semacam pantun atau gurindam.

Ada beberapa jenis dari karungut yaitu karungut cinta, karungut dongeng, karungut nasehat, karungut sansana bandar, dan karungut antang ngambun. Selain sastra lisan karungut juga sebagai sumber pembelajaran sejarah karena karungut sudah sejak dahulu dan diwariskan secara turun temurun yang disebarkan dalam bentuk lisan. Contohnya adalah Sastra lisan adalah karya sastra yang berbentuk ujaran. 
Salah satu sastra lisan di Kalimantan Tengah adalah karungut. Karungut adalah sebuah kesenian tradisional dari Kalimantan Tengah. Seni ini berupa sastra lisan atau juga bisa disebut pantun yang dilagukan. Karungut merupakan karya yang dijunjung masyarakat Dayak sebagai sastra besar klasik dan merupakan semacam pantun atau gurindam.

\section{Kesenian Bersifat Publikasi}

Kesenian ini biasanya memang dibuat untuk dipublikasikan/ dijual oleh masyarakat setempat untuk tamu yang datang ke Desa Tumbang Manggu. Seperti tari, musik, anyaman, pahat dan lukisan.

\section{c. Upaya Yang Dilakukan Oleh Masyarakat Desa Tumbang MangguUntuk Menjaga Kelestarian Kesenian}

Indonesia merupakan bangsa yang sangat kaya akan khasanah seni budaya. Beragam seni budaya yang ada merupakan aset dan telah menjadi jati diri bangsa Indonesia. Keragaman seni budaya Indonesia sudah sangat terkenal hampir diseluruh belahan dunia. Keunikan dari keragaman seni budaya yang ada selalu menjadi pertimbangan dalam pelestariannya.

Pelestarian seni budaya akan dapat dilakukan dengan baik apabila unsur-unsur yang ada didalamnya saling mendukung satu sama lain. Unsur seni budaya yang ada menjadi kekuatan yang akan selalu menopang kelangsungan seni budaya tersebut. Selain menjadi penopang seni budaya juga menjadi suatu kebanggan masyarakat pendukungnya.

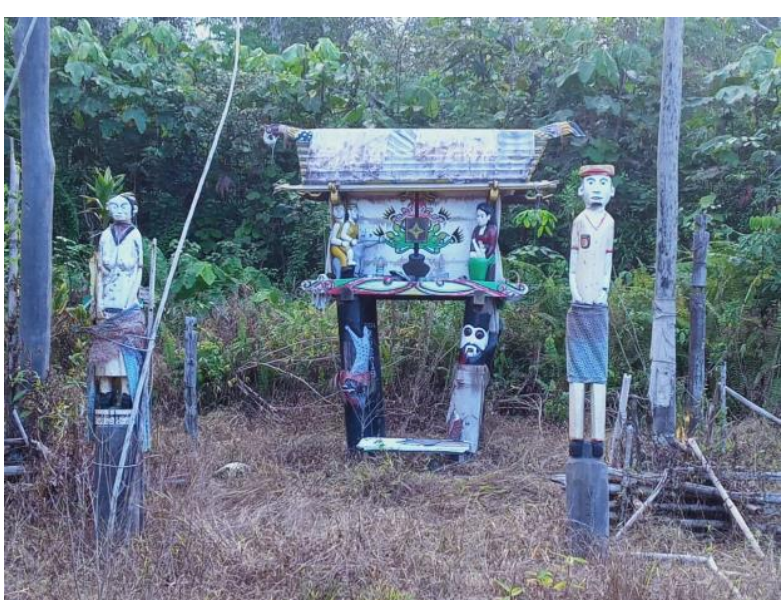

Gambar 4

Hal tersebut karena seni budaya memiliki nilai yang tidak dapat dipisahkan dari tata kehidupan masyarakat (Kusworo Waluyo, Upacara Badewa, 2005, hal. 1) Melihat hal diatas maka kesenian yang merupakan bagian dari kebudayaan merupakan bagian dari kehidupan manusia yang sangat mempengaruhi kehidupan disekelilingnya. Dan kesenian tidak akan pernah dapat terganti ataupun musnah bila kita mau melihat kesenian sebagai bagian dari kehidupan kita. Tidak terkecuali di Kalimantan Tengah.

Anggen dari Katingan pada acara interaktif televisi TVRI Palangka Raya 2009 berkomentar bahwa ancaman tersebut dikarenakan selama tiga periode yang menjadi penanggung jawab pertama Provinsi Kalimantan Tengah adalah orangorang dari Jawa yang sama sekali tidak menaruh perhatian pada kebudayaan Dayak sedangkan Gubernur berikutnya adalah Warsito Suparmanto yaitu Asmawi A. Gani sama sekali tidak mempunyai wacana kebudayaan (Kusni \& A.M., 2011, hal. 215).

Seiring berkembangnya zaman dan teknologi yang semakin canggih nilai-nilai kesenian daerah mulai pudar dan perlahan hilang. Untuk mencegah hal itu terjadi masyarakat Desa Tumbang Manggu membentuk sebuah sanggar dan memperkenalkan kesenian daerah kepada pelajar yang ada di daerah tersebut, agar 
kesenian tidak dilupakan oleh generasi penerus dan ada hingga masa yang akan datang. Dari sanggar yg didirikan ini lah para pelajar mempelajari kesenian tari, musik, meganyam, memahat dan melukis serta memperkenalkan kepada masyarakat luas dengan cara mengikuti lomba-lomba yang ada. Pelestarian dan memperkenalkan tidak cukup dilakukan dengan kegiatan setahun sekali. Pelestarian dilakukan dengan pembelajaran agar apa yang dipelajari itu dapat dikuasai. Disinilah peran sanggar, komunitas, galeri dan muatan lokal (mulok).

Pelestarian sebenarnya tidak lebih dari upaya meregistrasi segala apa yang kita miliki (Sulang \& A.M., 2011, hal. 167) Adapun solusi yangsehari-hari dilakukan masyarakat di Desa Tumbang Manggu yaitu:

1) Mengingatkan dan saling mengarahkan satu sama lain tentang pelaksanaan dan berbagai kesenian yang ada. Dengan demikian kesenian ini akan tetap berjalan sebagaimana mestinya.

2) Mengikutsertakan generasi muda dalam setiap dalam kegiatan sehari-hari dan dalam kegiatan adat. Misalnya kegiatan pembuatan kesenian seperti menganyam atau membuat alat lain, acara adat seperti perkawinan, kematian dan sebagainya. Dengan demikian mereka dapat melihat secara langsung dan menimbulkan ketertarikan untuk mempelajarinya. Bagaimanapun kelak jika mereka sudah dewasa dan berumah tangga sebagai masyarakat Tumbang Manggu mereka harus memahami tersebut.

3) Mengajarkan kesenian-kesenian tersebut secara rinci dan mendasar kepada orang yang berbeda suku. Dengan demikian secara perlahan mereka akan mengerti dan memahami tentang kesenian yang ada di Desa Tumbang Manggu
Kesenian asing yang lebih modern nampaknya lebih mampu menangkap dan lebih adaptif terhadap perubahanperubahan cepat yang terjadi di masyarakat, serta lebih memenuhi selera generasi muda yang lebih jenuh dengan kepengapan lingkungan tradisi. Sementara seni tradisional lokal dianggap cenderung statis, dari aspek substansi, materi, maupun metodologinya. Akibatnya, kesenian dianggap tidak lagi memadai untuk mewadai kebutuhan dan ekspresi masyarakat yang terus berkembang. Banyak hal yang dapat dilakukan untuk mengenalkan sesuatu, tidak terkecuali seni budaya.

Salah satu cara adalah dengan cara mengangkat seni budaya itu sendiri kedalam bentuk karya tulis misalnya, pengangkatan dengan cara penulisan ke dalam sebuah deskripsi akan lebih mudah untuk dipelajari, karena semua paparan yang disajikan lebih rinci dan inovatif (Kusworo Waluyo, Upacara Badewa, 2005, hal. 3). Pada Kalimantan Tengah, festifal seni budaya sejak pemekaran diselenggarakan diberbagai kabupaten secara susul-menyusul silih berganti. Kapuas, Seruyan, Katingan, Barito, Kota Waringin Baratdan Timur misalnya menyelenggarakan festifal-festifal kesenian. Melalui kegiatan-kegiatan ini nampak benar potensi dan warisan budaya daerah-daerah aliran sungai. Nampak ragam serta kemungkinan-kemungkinan cerah yang menanti seandainya diorganisasi, dikelola, dikembangkan secara tekun dan sadar di bawah konsep yang jelas.

Melihat kompleksnya masalah yang ada mulai dari syarat yang harus dipenuhi, penolakan generasi penerusnya, serta adanya modernisasi yang lebih terkenal tidaklah mudah kiranya untuk dapat mempertahankan kesenian suatu Suku. Namun dengan alasan apapun kesenian tersebut harus tetap dilestarikan, sebab 
bila tidak dilakukan kesenian tersebut akan punah secara perlahan dan kita akan kehilangan aset budaya bangsa sebagai peninggalan nenek moyang kita yang sangat berharga.

Mencermati fenomena modern, budaya lokal perlu diperkuat eksistensinya oleh komponen yang mendukung dibelakangnya. Persaingan memang kadang tidak adil, yang lemah akan dikalahkan oleh yang kuat. Diperlukannya proteksi yang memberdayakan, bukan yang meninabobokan. Disinilah letak perlunya langkah-langkah yang bijaksana. Budaya lokal, semisal di Kalimantan Tengah, selayaknya berani mengedepankan berbagai kearifan lokal yang bisa ditawarkan dalam percaturan nasional, sehingga menumbuhkembangkan yang lokal sekaligus diapresiasi ditingkat bnasional (Kusni \& A.M., 2011, hal. 17).

\section{KESIMPULAN}

Berdasarkan uraian yang telah dikemukakan pada bab-bab sebelumnya, serta analisis yang dilakukan maka kesimpulan data dari penelitian kami yang berjudul Eksplorasi Kekayaan Seni Kecamatan Sanaman Mantikei Kabupaten Katingan adalah masih banyak kesenian yang ditemukan. Pada Desa Tumbang Manggu dari kesenian musik, tari, menganyam, memahat serta melukis masih bisa terjaga dan dimanfaatkan oleh masyarakat setempat. Berbagai alat pemenuh kebutuhan dari kesenian ini menjadi penunjang hidup disana. Manfaaat kesenian untuk masyarakat Tumbang Manggu sebagai Kesenian yang bersifat sakral, kesenian yang bersifat hiburan dan kesenian yang bersifat publikasi. Peranan anak bangsa dalam kelestarian kesenian ini sangat berpengaruh dalam pelestariannya. Dengan melestarikan kesenian yang sudah ada sejak zaman dahulu, sangat membantu untuk meminimalisir kepunahan seni. Masyarakat Desa Tumbang Manggu membentuk sebuah sanggar dan memperkenalkan kesenian daerah kepada pelajar yang ada di daerah tersebut, agar kesenian tidak dilupakan oleh generasi penerus dan ada hingga masa yang akan datang.

Kami berharap tulisan ini bermanfaat bagi pelajar, mahasiswa, dan masyarakat luas dalam memahami lebih dalam lagi mengenai kesenian suku dayak tepatnya di Desa Tumbang manggu. Dan menjadi jembatan ilmu bagi penulis maupun pembaca terutama dalam bidang kesenian tradisional masyarakat Dayak. Dalam hal ini kami membutuhkan saran dan kritik dari pembaca agar kami dapat membangun proposal ini menjadi lebih baik lagi.

\section{DAFTAR PUSTAKA}

Dr. J.R. Raco, M. (2010). Metode Penelitian Kualitatif. Grasindo .

Edlin Yanuar Nugraheni, V. S. (2018). Makna Tari Kinyah Mandau Hatue Suku Dayak Kabupaten Kapuas. Unair, 45.

Gunawan, I. (2013 ). Metode Penelitian Kualitatif . The Learning University , 2-3.

Gustiningrum. (2016). Memaknai Nilai Kesenian Kuda Ronggeng Dalam Melestarikan Budaya Daerah Di Kabupaten Sumedang. Journal Of Urban Society's Arts, 28-29.

K. S., \& A. S. (2011). Buda Dayak. Malang: Bayu Media.

K. S., \& A. S. (2011). Budaya Dayak, Permasalahan Dan Alternatifnya. Malang: Bayumedia.

K. W., \& D. P. (2009). Organisasi Sosial Lokal Sukubangsa Dayak Ngaju Di Kalimantan Tengah.

Jakarta: Direktorat Jendral Nilai Budaya, Seni Dan Film.

Katabung, W. (2018). Filsafat Agama Hindu.

Kusworo Waluyo, M. (2005). Upacara Badewa. Nunukan: Pemda Kalimantan Timur.

Muhammad Takari, D. (2008). Masyarakat Kesenian Di Indonesia. Medan: Studio Kultura. 
Nurul Amalia, B. H. (2015). Bentuk Dan Fungsi Kesenian Tradisional Krangkeng Di Desa. Unnes , 1-2.

Nurgiansah, T. H. (2020a). Build An Attitude of Nationalism Students At SDN 7 Kadipaten With The Method of Discusion In The Subject PPKn. Jurnal Serunai Pendidikan Pancasila Dan Kewarganegaraan STKIP Budi Daya Binjai, 9(1), 1-11.

Nurgiansah, T. H. (2020b). Filsafat Pendidikan. In Banyumas: CV Pena Persada.

Nurgiansah, T. H. (2021). Pendidikan Pancasila. In Solok: CV Mitra Cendekia Media.

Romein Armando. (2021). Jejak Sejarah Dalam Sastra Lisan Di Kalimantan Tengah . Preprints , 1-2.

Soemadio, R. W. (2010). Budaya Masyarakat Dayak. Jakarta Barat: Pt. Multi Kreasi Satu Delapan.

Soemadio, R. W. (2010). Budaya Masyarakat Dayak. Jakarta Barat: Multi Kreasi Satudelapan.

Sulang, K., \& A. S. (2011). Budaya Dayak. Malang: Bayumedia.

Tindaon, R. (2012). Ekspresi Seni. Jurnal Ilmu Pengetahuan Dan Karya Seni.

Umberan, H. D. (2015). Jakarta: Departemen Pendidikan Dan Kebudayaan Daerah Pusat.

Yandi, D. (2014). Palankaraya: Bloger Kalteng.

Https://Www.Humanitarianresponse.Info/Sites/Www.Humanitarianresponse.Info/Files/Doc uments/Files/Kalimantan_Tengah.Pdf

Https://Sippa.Ciptakarya.Pu.Go.Id/Sippa_Online/Ws_File/Dokumen_Usulan/File_Attachment /Rpi2jm\%20final/Pdf2015/Bab\%20iv\%20-\%20gambaran\%20umum.Pdf 